methods and techniques. An essential feature of the concept is the provision of mobile laboratories, and it is proposed to establish twenty regional units in the United Kingdom, each equipped with a mobile laboratory near which students and staff live under canvas. The organization possesses a small farmhouse and twenty acres of land near Hebden Bridge in Yorkshire. It is intended to convert the farmhouse to provide hostel-type accommodation and to establish there a training centre for scientists going overseas. In the mobile units the use of modern frame tents, together with larger marquee tents, makes it possible to provide very comfortable working conditions. The laboratory itself in the prototype unit is contained in a three-ton box-bodied vehicle with working space inside and outside the body. The working space outside is enclosed in heavy canvas screens and is used for preliminary investigation and identification. Critical work is performed in the body of the vehicle, which is airconditioned and can be darkened for photographic processing. The body of the vehicle is stabilized by jacks on all corners to allow microscopes to be used at high powers without difficulty. Future laboratories will be contained in large trailers which, with side extensions formed by the sides swinging up to form the roof extension and screened around, will provide an open space $22 \mathrm{ft} . \times 20 \mathrm{ft}$. The mobile overseas research unit comprises two five-ton and two thirty-hundredweight trucks; all have 4-wheel drive and are equipped with power winches, etc. Each vehicle has a radio receiver and the field base is equipped with a long-range transmitter. Trailers carry pumps, purification and filtration plants, and air-conditioning plant, compressor and generator, as well as water and petrol. One of the five-ton trucks is a field laboratory, the other serves as a workshop and stores. The organization also maintains a stock of equipment for biological field work which is available for hire by schools, universities, societies, etc. Further information may be obtained from: Bio-Probe, Scientific Field Research Unit, 7 Kingsgate, Red Lion Square, London, W.C.1.

\section{Turbulent Boundary Layers in Compressible Gases}

THE book entitled Turbulent Boundary Layers in Compressible Gases, by S. S. Kutateladze and A. I. Leont'ev (translated from the Russian by Prof. D. B. Spalding), which was reviewed on p. 227 of the April 17 issue of Nature, while published by Academic Press, Inc., New York, in the United States, is published by Edward Arnold (Publishers), Ltd., in the United Kingdom. The price is $60 s$. and not $68 s$. as stated in the bibliography to the review.

\section{The Night Sky in June}

FutL Moon occurs on June 14d 02h U.T. and new Moon occurs on June $29 \mathrm{~d} 05 \mathrm{~h}$. There is a partial eclipse of the Moon on June 13-14 visible at Greenwich. The Moon enters the penumbra June J3d $23 \mathrm{~h} 15 \mathrm{~m}$ leaving on June $14 \mathrm{~d} 04 \mathrm{~h} 22 \mathrm{~m}$ and enters the umbra on June $14 \mathrm{~d} 00 \mathrm{~h} 58 \mathrm{~m}$ leaving on June $14 \mathrm{~d} 02 \mathrm{~h} 40 \mathrm{~m}$. The time of mid-eclipse is June $14 \mathrm{~d} 0 \mathrm{lh} 49 \mathrm{~m}$. The following conjunctions with the Moon occur: June 6d I6h, Mars $5^{\circ}$ S.; June 2ld 01h, Saturn $4^{\circ}$ N. Mercury is unfavourably placed for observation during the month. Venus sets at $21 \mathrm{~h} 15 \mathrm{~m}, 21 \mathrm{~h} 40 \mathrm{~m}$, $2 \mathrm{lh} 40 \mathrm{~m}$ on June 1, 14 and 29 respectively; its stellar magnitude is $-\mathbf{3} \cdot \mathbf{3}$ and its distance from the Earth on June 15 is 151 million miles. Mars sets at $1 \mathrm{~h} 20 \mathrm{~m}, 0 \mathrm{~h}$ $25 \mathrm{~m}, 23 \mathrm{~h} 40 \mathrm{~m}$ at the beginning, middle and end of the month respectively; its stellar magnitude is +0.8 ; its distance from the Earth on June 15 is 114 million miles and moves into Virgo in the middle of the month. Jupiter rises at $3 \mathrm{~h} 00 \mathrm{~m}, 2 \mathrm{~h} 15 \mathrm{~m}$ at the middle and end of the month, respectively -only becoming observable by the end of the month. Saturn rises at ih $15 \mathrm{~m}, 0 \mathrm{~h} 10 \mathrm{~m}$, $23 \mathrm{~h} 15 \mathrm{~m}$ at the beginning, middle and end of the month respectively; its stellar magnitude is $+1 \cdot 2$; its distance from the Earth on June 15 is 886 million miles and is in Aquarius. There are no occultations of stars brighter than magnitude 6. The summer solstice occurs on June 21d $15 \mathrm{~h}$.

\section{University News :}

Birmingham

THE thirty-fifth annual report on research and publications of the University Research Committee, University of Birmingham, summarizes departmental progress in research during the academic year 1963-64 (Pp. 177. Birmingham: the University, 1965). Under each department particulars are given of publications during the year, and the titles of theses approved for higher degrees.

Bristol

Dr. A. J. BuLLer, reader in physiology at King's College, London, has been appointed to the chair of physiology from August 1. Mr. J. F. Baldwin has been appointed lecturer in theoretical mechanics from August 1.

Reading

DR. D. BRyce-SmitH, at present reader in the Department of Chemistry, has been appointed to the newly established chair of organic chemistry as from June I.

Southampton

THE following appointments have been announced: Readerships, Dr. A. W. Bright (electrical engineering); Dr. L. G. E. Bell (zoology); Senior Lectureship, Mr. W. A Matthews (psychology); Lectureships, Mr. K. J. Binns (electrical engineering); Mr. B. R. Wilkins and Mr. J. A. Betts (electronics); Mr. F. A. Bostock, Mr. M. S. P. Eastham, Mr. I. J. Ketley, Mr. L. G. Proll and Mr. B. S. Westcott (mathematics); Mr. R. D. Wills (physics); Mr. W. T. Drabble, Mr. B. J. Parsons and Mr. G. N. Woodruff (physiology and biochemistry); Mr. F. S. Billett (zoology).

\section{Announcements}

Mr. R. O. R. CHisнorm, chief project officer in the Guided Weapons Division, Bristol Aircraft Corporation, has been awarded the Prince Philip Medal for 1963 of the City and Guilds of London Institute, for outstanding achievement in science and technology.

Dr. Alfred H. Sturtevant, well known for his work on modern genetic theory through his analysis of hereditary patterns in the common fruit fly, Drosophila melanogaster, has been awarded the Carty Medal of the U.S. National Academy of Sciences. The Medal is given "for noteworthy and distinguished accomplishment in any field of science coming within the scope of the charter of the Academy".

THE nineteenth Radio and Electronic Component Show will be held at Olympia, London, during May 18-21. Further information can be obtained from Industrial Exhibitions, Ltd., 9 Argyll Street, London, W.1.

OPEN days will be held at the National Physical Laboratory (incorporating the former National Chemical Laboratory) during May 19-20. Further information can be obtained from the National Physical Laboratory, Teddington, Middlesex.

A SPECIAL meeting of the Society for Analytical Chemistry will be held at the Chemical Society, London, on May 19. A lecture on "Analytical Aspects of Chronopotentiometry" will be delivered by Prof. J. J. Lingane (Harvard University). Further information can be obtained from the Society for Analytical Chemistry, 14 Belgrave Square, London, S.W.1.

Corrigendum. In the communication "Renin-angiotensin System in the Spontaneously Hypertensive Rat" by Dr. H. Sokabe, which appears on p. 90 of the January 2, 1965 , issue of Nature, " $F$ " on line 4 should read " $F$ ", and " $10^{-5} \mathrm{M}$ " on line 22 should read " $10^{-2} \mathrm{M}$ ". 